\title{
Redactioneel drieluik: een generatie BMO en TMO
}

\author{
R. Remmen, J.C.M. Metz, G.M. Verwijnen
}

\section{Samenvatting}

Als twintig jaar een generatie is, heeft het tijdschrift van de Nederlandse Vereniging voor Medisch Onderwijs er zijn eerste generatie opzitten. In dit drieluik schrijven drie redactieleden over 'hun' tijdschrift. De bijdragen van twee van hen, Jaap Metz en Maarten Verwijnen, omspannen vrijwel de gehele bestaansduur van Bulletin en Tijdschrift. Kijk er de index maar op na. Daarnaast zou Jaap, als redacteur van het Raamplan, wel eens de meest geciteerde auteur in dit tijdschrift kunnen zijn. Zij zetten Albert Scherpbier, de eerste hoofdredacteur deze titel werd bij de professionalisering van BMO tot TMO passender gevonden - van TMO in het zonnetje. Tegelijkertijd getuigen zij van het plezier en de collegiale betrokkenheid die kenmerkend is voor de makers van dit tijdschrift. Een tijdschrift maak je omdat het leuk is en je er veel van leert. Roy Remmen vertegenwoordigt de nieuwe redactionele generatie. Door zijn Vlaamse bril kijkt hij naar de toekomst. De ontwikkelingen in het Vlaamse medisch onderwijs hebben al verschillende publicaties in TMO opgeleverd. Het is Roy toevertrouwd de TMO-lezers op onderhoudende wijze in te lichten over interessante zaken in het medisch onderwijs ook tot ver buiten de Vlaams/Hollandse grenzen. Jaap Metz schetst een trefzeker beeld van de groei van tijdschrift en redactie. Maarten neemt met een heel persoonlijke terugblik ook zelf afscheid van de redactie. Op zijn bescheiden en toch ook opvallende wijze heeft hij daarin een belangrijke rol gespeeld. Veel artikelen zijn mede door zijn enthousiasme tot stand gekomen. Veel auteurs heeft hij met 'leerzame feedback' geholpen het schrijfproces met succes af te ronden. Al schrijvend en lezend met en van elkaar leren, dat is de drijvende kracht achter dit tijdschrift. De index laat zien wie bijdragen geleverd hebben en waarover zoal geschreven is. Het is spannend om te zien door wie en waarover er in de toekomst in het TMO geschreven zal worden.

\section{De NVMO en TMO een beetje Vlaams?}

Bij de wissel van hoofdredacteurschap is het ook nuttig om even over de grens te kijken. Onze vereniging is de Nederlandse Vereniging voor Medisch Onderwijs. Het potientiële lezerspubliek bestaat kun je zeggen uit 15 miljoen Nederlanders. Hoe is het gesteld met het aandeel van de 6 miljoen Vlamingen, die zo dichtbij aanwezig zijn?

De laatste jaren kunnen we spreken van een renaissance van het Vlaamse academische landschap. Alle faculteiten pakken uit met vernieuwing van curricula, positief gestuurd door de aanbevelingen van de laatste visitatie van de medische faculteiten. Zo zijn aan mijn eigen instelling grote veranderingen doorgevoerd op structureel en procesniveau. Bijvoorbeeld, we hebben aan onze instelling enkele fte's verkregen om goed onderwijs te maken (onderwijskundige ondersteuning, enkele parttimers op het vaardighedenonderwijs, longitudinale vaardigheidstoetsing, geïntegreerd onderwijs). Ook in andere instellingen hebben er min of meer grote veranderingen plaatsgevonden. En 
Tabel 1. Overzicht van het ledenaantal van de NVMO verdeeld naar Nederland en Vlaanderen.

\begin{tabular}{lll}
\hline Jaar & Nederland (15 miljoen inwoners) & Vlaanderen (6 miljoen inwoners) \\
\hline & & 14 \\
1999 & 510 & 22 \\
2001 & 586 & \\
\hline
\end{tabular}

steeds wordt er een beetje gekeken naar hoe de zusterinstellingen het doen, en in het kleine Vlaanderen kijken we daarom ook nogaleens naar Nederland.

Ook op medisch onderwijskundig niveau is er sprake van een goede ontwikkeling. We hebben in Vlaanderen enkele medisch-onderwijskundige proefschriften afgeleverd en in toenemende mate wordt er Vlaams gesproken op het jaarlijks ledencongres (ongeveer 30 van de ruim 400 congresgangers zijn de laatste jaren Vlamingen). Ook in het buitenland wordt er vaker Vlaams-Engels gesproken. Daarnaast is opvallend dat de Vlaamse academische huisartsgeneeskunde een belangrijke rol speelt in de renaissance. Blijkbaar staan zij niet alleen dicht bij de patiënt maar ook dicht bij de student.

Toch missen we in Vlaanderen soms nog de kritische massa om echt aan de weg te timmeren aan nog beter medisch onderwijs. Bijna alle arts-academici die ik ken en die betrokken zijn bij de ontwikkeling van het medisch onderwijs (en ik bedoel nu dus niet het geven van onderwijs aan studenten) doen dit voor een groot deel buiten hun aanstelling en dus als een nevenactiviteit. Op die manier kan er van een echte professionele specialisatie, zoals die bijvoorbeeld aan sommige Nederlandse faculteiten wel mogelijk is, geen sprake zijn.

Terug naar het belang van die 6 miljoen Vlamingen. In tabel 1 ziet $\mathrm{u}$ dat er naast de aanwezigheid op het congres ook nog steeds een significante ondervertegenwoordiging is van het aantal Vlaamse leden. Het Vlaamse 'marktaandeel', zou een ondernemer stellen, moet uitgebreid kunnen worden. Bij zo'n uitbreiding heeft iedereen baat. De NVMO kan dan inderdaad een regionale functie vervullen in Europa. Meer lidmaatschap geeft aanleiding tot meer contacten en zal in die zin ook leiden tot betere opleidingen aan beide kanten van de, laten we eerlijk zijn, steeds meer onzichtbare grens.

\section{Roy Remmen}

November 2002

\section{Bij het afscheid van Albert Scherpbier}

Een met mij bevriend theoloog zag eens, lang geleden, een in het oog vallend stapeltje mariablauw gekleurde tijdschriften liggen, dat ik quasi losjes op mijn bureau had gedrapeerd. Hij vroeg wat dat was, en ik vertelde trots dat het de eerste afleveringen waren van een nieuw tijdschrift op het gebied van medisch onderwijs. 'Een tijdschrift over medisch onderwijs? Wat kan daar dan zoal in staan? Waar er al tijdschriften over bestaan.' Na enige minuten te hebben gebladerd en geneuzeld: 'het wordt wel volgeschreven door ene Scherpbier.' Het valt dus kennelijk ook de buitenstaander op, dat de naam van Albert Scherpbier direct valt als men kennis neemt van het TMO en de verschillende ontwikkelingsstadia daarvan.

De eerste afleveringen van het gestencilde blaadje dat toen nog Bulletin Medisch Onderwijs heette, bevatten al artikelen van zijn hand. Kritische kanttekeningen 
bij het artsexamen, als ik mij goed herinner. We leefden destijds nog ruimschoots in de 20 e eeuw en Albert zat hoog, droog en nauwelijks als arts afgestudeerd als onderwijscoördinator op de Chirurgie in Groningen; en niet in de redactie.

Als verenigingstijdschrift van de NVMO heeft het Bulletin steeds de ontwikkeling van de NVMO weerspiegeld: van informeel clubblaadje tot officieel tijdschrift. In die beginjaren bestond de NVMO uit een kleine club van enkele tientallen, toen nog vooral preklinische onderwijsfreaks. Enkele 'angry young men' - Albert voldeed aan alle criteria - maakten zich druk over het klinisch onderwijs en zagen hun kritiek en ideeën maar al te graag geplaatst in het Bulletin. Het waren vingeroefeningen: tips op het gebied van het vaardigheidsonderwijs, kritiek op het traditionele artsexamen, een klein onderzoeksverslag over de betrouwbaarheid van examinatoren.

De toenmalige redactie werd steeds vaker belast met de plicht om zelf het blad vol te schrijven bij gebrek aan kopij. Dat was niet vol te houden. Na enkele jaren ging het blaadje dan ook tijdelijk ter ziele en niemand leek te treuren. Maar het kwam terug: in nieuwe gedaante, met een nieuwe redactie met daarin een prominente rol van Albert, zowel inhoudelijk als op het gebied van de lay-out. Dat is een typisch kenmerk van Albert: die permanente aandacht voor de combinatie van een kritische boodschap verpakt in een zo volmaakt mogelijke vorm. Het uiterlijk van het tijdschrift ging hem zeer ter harte. Hij benaderde zelf ontwerpers en uitgevers om zijn ideeën gerealiseerd te krijgen.

Wat betreft de inhoudelijke boodschap: hij had van meet af aan een paar punten waarop hij steeds op zijn eigen wijze hamerde: met zachte stem, een knipoog, veelal in vragende vorm, maar wel iedere keer weer: onderwijs heeft - net als andere universitaire taken - een wetenschappelijke benadering nodig, stellingnames moeten door resultaten van onderzoek ondersteund of onderuitgehaald worden (evidence-based teaching), ook op het gebied van het medisch onderwijs is er behoefte aan een scientific community, waarvan een tijdschrift een onontbeerlijk onderdeel vormt. Een wetenschappelijk tijdschrift: jaren heeft hij zich nijdig gemaakt over de term 'bulletin', die ongewenste associaties aan het oude clubblaadje zou levend houden. Tegenargumenten, zoals het verwijzen naar een achtenswaardig tijdschrift als Psychological Bulletin, deerden hem niet. Door het hameren heeft hij uiteindelijk een paar jaar geleden zijn zin gekregen toen de naam van het tijdschrift werd gewijzigd in de door hem al jaren bepleite richting.

Binnen het team van de nieuwe redactie die aan het begin van de 80 er jaren aantrad, was hij lange tijd de informele hoofdredacteur. Een formele hoofdredacteur was er niet. Er was - zoals wel vaker in die tijd - geen behoefte aan een dergelijke als hiërarchisch beleefde taakverdeling binnen de redactie. Als jongste wilde hij ook niet ouderen passeren, de term hoofdredacteur werd door hem bij herhaling gerelativeerd en toch was hij vrijwel steeds degene die nieuwe thema's aansneed, conceptteksten van auteurs wijzigde, soms herschreef en altijd op referenties, interpunctie corrigeerde. Hij had geen behoefte aan de titel 'hoofdredacteur', terwijl hij het feitelijk - ook voor de mederedacteuren - wèl was.

Jaren later - het tijdschrift professionaliseerde zich steeds verder - toen de functies van redacteur, redactiesecretaris en uitgever niet meer in één persoon te verenigen waren, ging Albert - de term nood- 
gedwongen dringt zich op - akkoord met een rol als eindredacteur. Nog steeds geen hoofdredacteur dus, maar wel de centrale figuur, die naast inhoud ook met vormgeving was belast. De laatste jaren was Albert formeel hoofdredacteur, en van die functie doet hij nu afstand. Het zou mij niets verbazen als hij - zoals zo vaak op de achtergrond - nog vele jaren bij het tijdschrift betrokken zal blijven.

Zoals het TMO de ontwikkeling van de NVMO weerspiegelt, zo reflecteert de rol van Albert bij het tijdschrift zijn loopbaan als geheel: van meet af aan voor ogen wat hij wil, stap voor stap daar naar toe werken, continu zijn gezag verhogend, niet door formele machtsposities, maar door inhoudelijk overwicht, bepaald door kritische instelling, enorme belezenheid en een - ogenschijnlijk daarmee in tegenspraak - grenzeloze precisie en accuratesse, steeds gepaard aan jeugdige eenvoud en informele manieren en een bescheiden, op de achtergrond blijvende instelling. Met zo iemand samen te werken, bij de totstandkoming van een artikel, van een aflevering van een tijdschrift, van een congresverslag, van een boek, is een uniek voorrecht.

Nijmegen, 13 januari 2003

Jaap Metz

\section{Beste Albert,}

Als bijdrage aan de afsluiting van je TMO-redactieperiode heb ik ervoor gekozen om je een persoonlijke boodschap te schrijven. Dat past goed in het contact dat wij inmiddels al ruim 15 jaar hebben, sinds onze eerste ontmoeting als NVMObestuursleden. Ik was daar een paar jaar tevoren Evert Reerink vanuit Maastricht opgevolgd en jij kwam als opvolger van Wim Bender Groningen vertegenwoordi- gen. We ontdekten al snel dat we heel erg gelijkgestemd met ons werk, het medisch onderwijs, bezig waren en er graag met elkaar over praatten. Het past ook goed bij jouw werkstijl, waarin veel plaats is voor persoonlijk contact, waar werk en privé samenkomen en waar ook vriendschap en kameraadschap ontstaan. Erg kenmerkend voor al je professionele contacten. Veel vriendschappen, zowel met collega's als studenten zijn zo ontstaan en worden zo door jou onderhouden. Zo ook onze vriendschap, waarin ik je zorgzaamheid zeer waardeer. Ik wil deze gelegenheid gebruiken of misschien wel een beetje misbruiken om je te huldigen. Je houdt daar niet van, maar ik vind een eerbetoon wel op z'n plaats. Het is nu eenmaal zo dat het TMO van nu, grotendeels het product van jouw bemoeienissen is. Ik denk dat iedereen vindt dat je dat hartstikke goed gedaan hebt.

Kort na je start als NVMO-bestuurslid mochten Herman van Rossum, Caspar Bleys en ik je in 1987 verwelkomen binnen de redactie van het toenmalige Bulletin Medisch Onderwijs. Vijf jaar eerder begonnen als een eenvoudig gestencild verenigingsblaadje. Dat was het op dat moment nog steeds, maar met jouw komst groeide het al ras en gestaag uit tot het volwaardig wetenschappelijk tijdschrift van dit moment. Die ontwikkeling heb je zelf onlangs treffend beschreven, dus dat zal ik hier niet herhalen. ${ }^{1}$ Uiteraard hebben velen daaraan bijgedragen. Maar jouw aandacht voor professionalisering en je vermogen om mensen aan te spreken in hun bijzondere kwaliteiten (nu heet dat Human Resource Management) zijn in mijn ogen een belangrijke motor geweest. Binnen het medisch onderwijs van toen waren die begrippen nog bepaald geen gemeengoed, maar ik heb ze bij jou leren kennen als twee heel vanzelf- 
sprekende zaken in je dagelijks werk en daardoor ook in ons redactiewerk. Vooral die vanzelfsprekendheid vind ik kenmerkend voor jou. Het zijn voor jou geen 'issues' waar gewichtig over gesproken of geschreven moet worden, maar zaken die je gewoon doet, die er van nature bijhoren. Ik ben ervan overtuigd dat dit kenmerk van je werkstijl in belangrijke mate heeft bijgedragen aan de professionalisering van het tijdschrift en ook velen heeft geïnspireerd bij de professionalisering van het medisch onderwijs in Nederland. Je zorgzaamheid hierbij voor ieders persoonlijke kwaliteiten vind ik behartenswaardig en erg leerzaam. Dat brengt me meteen op een andere eigen-aardigheid van jou waar ik het even over wil hebben: ... aandacht voor leren. Bijna alles wat je doet, staat in het teken van leren. Veel keuzes die je maakt, doe je welbewust met het oogmerk om te leren. Leren, dus niet 'onderwezen worden', staat centraal, ook het leren van anderen. Een onderneming heeft voor jou pas zin als er van geleerd kan worden. Die instelling is voor mij binnen de redactie van het TMO een heel inspirerende leidraad geweest. Voor jou is het TMO eerst en vooral een leerzaam tijdschrift. Niet alleen voor de lezers maar ook voor de auteurs en redactie. Geen redactie dus, die beoordeelt en selecteert, maar een redactie die leert leerzame feedback te geven en zo bijdraagt aan het leren van auteurs. Auteurs die zo leren om goeie artikelen te schrijven en zo het medisch onderwijs professionaliseren. "Schrijven is een ideale vorm van bij- en nascholing" schreef je laatst. ${ }^{1}$ Ik denk dat je gelijk hebt. Voor jouw aandacht en zorg daarvoor binnen de redactie van het TMO ben ik je zeer erkentelijk. Daarom vind ik het ook zo aardig, dat we dit speciale nummer van het TMO gebruiken om afscheid van je nemen. Dit is immers hele- maal jouw nummer. Een index van alle artikelen sinds het prille begin. In vrijwel al deze artikelen heb jij de hand gehad. In heel veel als (mede)auteur, in bijna allemaal als (eind)redacteur, en het was altijd leerzaam! Dit nummer van het TMO is in feite de weerslag van jouw bijdrage(n?!) aan het medisch onderwijs tot nu toe. Niet mis, maar wel makkelijk gemist! Daarom goed, dat we jou in dit nummer even voor het voetlicht halen. Dit nummer zal vaak ter hand genomen worden en dan is je naam niet te missen. Ik vind dat je dat heel erg verdient. Bedankt voor je regie en ook gefeliciteerd ermee: 'goed gedaan, man!'

Dat je er als voorzitter van de NVMO een vruchtbare voortzetting aan zal geven met als motto een uitspraak van de roemruchte Sir Winston Churchill (1874-1965): "I am always willing to learn, but I am not always happy to be taught". ${ }^{2}$

Veel plezier en succces, Maarten, 13 januari 2003

\section{Literatuur}

1. Scherpbier AJJA. Afscheid [redactioneel]. Tijdschrift voor Medisch Onderwijs 2003;22(1):1-2.

2. Margadant SWF. Twintigduizend citaten. HP Leopolds Uitgeversmij NV, 's-Gravenhage; 1964. 